\title{
The Associated Factors Hampering Mothers towards Exclusive Breastfeeding EBF through Knowledge, Attitude and Practice (KAP) Studies at Al-Sabah Children Hospital /Juba -South Sudan
}

\author{
R Poni Gore*, Felix Tombe Lomeling, Awad Hussein Kareialla, Wani Bosco Fabiano A, Chol Mabil D Ajang, Wahib Natale Dan- \\ iel, John Mawich Nangdor, Joshua Jockjio Thor M, Ruai Mut Koang
}

Department of Community Medicine, University of Juba, South Sudan

${ }^{*}$ Corresponding author: R Poni Gore, Department of Community Medicine, University of Juba, South Sudan. Tel: +211955511872; E- Mail: roseponi196@gmail.com

Citation: Gore RP, Lomeling FT, Kareialla AH, Fabiano WBA, Mabil CD, et al. (2017) The Associated Factors Hampering Mothers towards Exclusive Breastfeeding EBF through Knowledge, Attitude and Practice (KAP) Studies at Al-Sabah Children Hospital /Juba -South Sudan. J Community Med Public Health : CMPH-101. DOI: 10.29011/CMPH-101/100001

\section{Abstract}

Introduction: Exclusive breastfeeding EBF is the feeding of an infant entirely with breast milk (i.e. via lactation). EBF is an important public health strategy for improving infant and child morbidity and mortality indicators, The World Health Organization (WHO) \&(UNICEF) recommend exclusively breastfeeding for the first 6months of life, EBF, improves the growth, and survival status of newborns and is best forms of prevention.

Goals: To assess the related factors hindering mothers knowledge, attitude and practices towards exclusive breast feeding of infants in Juba.

Methodology: Study design \& area: A questionnaire-based qualitative study was conducted on a group of 123 nursing mothers from December 2013 to 30th June 2014 to evaluate knowledge attitude and practices towards EBF, The sample size was selected randomly at AL-Sabah Hospital.

\section{Results: age range}

$54.5 \%$ of age $16-25 \mathrm{yrs}, 40.7 \%$ of $26-35 \mathrm{yrs}$ and finally $4 \%$ were $36-45 \mathrm{yrs}$. Educational level; $38.2 \%$ basic, $19.5 \%$ secondary, $7.3 \%$ university, $35 \%$ illiterate, (tot literate $65 \%$ ). Social status; $2.4 \%$ were single mothers, $92.7 \%$ were married, $4.1 \%$ divorced/ separated and $0.8 \%$ widow. Income; $8.1 \%$ self-employed, $12.2 \%$ employed both in private and public sector, $79.7 \%$ unemployed. Residence area; $22.0 \%$ of mothers from Juba, 26.0\% from Kator, 43.2\% from Munuki, and 9.7\% from Rajaf Religion background, $93.5 \%$ Christians, $5.7 \%$ Muslims and $0.8 \%$ no credo, bear chronic illness; $8.1 \%$ had chronic illness, $91.9 \%$ absent of chronic (medical report). ANC attendance; $77.2 \%$ regularly attended, $11.4 \%$ irregularly, $10.6 \%$ never been to ANC, and $0.8 \%$ do not know ANC, with house hold dependants; $16.3 \%$ had other infants, $19.5 \%$ had children of $>2$ years at $t$ home, $21.1 \%$ had adults $>60$ years old and $43.1 \%$ had no departments. Breastfeeding practice: $96.7 \%$ practicing breastfeeding only $3.3 \%$ not practicing breastfeeding.

The frequency during day: $59.3 \%$ were breastfed 8 times or more, $11.8 \%$ breastfed less than 8 times, $26.0 \%$ not sure and $3.3 \%$ not breastfed. Start of breastfeeding: $66.2 \%$ immediately after birth, $20.3 \%$ within hours, $13.8 \%$ within days and $3.3 \%$ not breastfeeding, knowledge about duration of EBF; $17.1 \%$ first 3 months, $67.5 \%$ first 6 months, $8.1 \%$ up-to 2 yrs and $7.3 \%$ don't know , Attitude to practice EBF; $85.4 \%$ Agree to EBF, $8.1 \%$ uncertain and 6.5\% disagree, complementary foods: $22.8 \%$ of infants introduced to complementary food before 4 months, 37.4\% between $4-6$ months, $30.9 \%$ after 6 months and $8.9 \%$ do not know, while $35 \%$ exclusively will breastfeed, $14.7 \%$ were given juice \& water, $4.9 \%$ were given soup , $45.5 \%$ were given others foods. interference breastfeeding with work productivity and payment : $27.6 \%$ of the women agree that time spent 


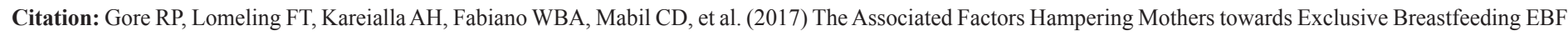
through Knowledge, Attitude and Practice (KAP) Studies at Al-Sabah Children Hospital /Juba -South Sudan. J Community Med Public Health : CMPH-101.

breastfeeding at work should not be paid but $73.4 \%$ disagree with not paying the time the mother spent breastfeeding at work place, Breastfeeding in public places: $52.8 \%$ agree when baby is hungry, $8.1 \%$ uncertain and $39.0 \%$ disagree, Knowledge about immune system of breastfed infant: $97.6 \%$ are aware that immune system of breastfed infant is stronger than formula-fed infant, only $2.4 \%$ do not know.

\section{Conclusions \& Recommendations}

Breastfeeding mothers are faced with multiple challenges to practice exclusive breastfeeding. Thus, scaling up of EBF among mothers requires concerted effort at all levels of South Sudanese Society. The promotion and acceptance of the EBF is vital in high level of poverty, Civil War, disease burden and low access to clean water and luck of adequate sanitation. The accessibility of Ante Natal Clinic ANC, training of Healthcare workers and counseling mothers are crucial, also the adoption and implementation of the WHO/UNICEF Global strategy for Infants and Young Child Feeding (IYCF) at all healthcare levels in the States of the Republic of South Sudan is paramount.

Keywords: Al-Sabah Children Hospital; Civil War; Complementary Food; Exclusive Breastfeeding EBF; illiteracy; lactating mothers; The World Health Organization (WHO), United Nations Children's Fund (UNICEF)

\section{Introduction and Literature Review}

Exclusive Breastfeeding EBF is the feeding of an infant or young child with breast milk directly from the mother's breast (i.e. via lactation) rather than using infant formula. It is an important public health strategy for improving infant and child morbidity and mortality, as well as maternal morbidity and helping to control health care costs [1] with the exception of oral rehydration solution, drops or syrups consisting of vitamins, minerals supplements or medicine. Historically, abandonment of breastfeeding began in higher socioeconomic level followed by a decrease in lower socioeconomic levels. As the trend was reversed, women in the upper socioeconomic levels were the first to show an increased incidence of breast feeding followed by progression down class line. A significant boost to breastfeeding came from the American Academy of Pediatrics (AAP), which in 1978 recommended that all Physicians encourage mothers to breast their babies. The World Health Organization (WHO) and United Nations Children's Fund (UNI$\mathrm{CEF}$ ) recommend that every infant should be exclusively breastfed for the first six months of life, with breastfeeding continuing for up to two years of age or longer. Exclusive Breastfeeding (EBF) for the first 6 months of life improves the growth, health and survival status of newborns [2]. And EBF is one of the most natural and best forms of preventive medicine. EBF plays a pivotal role in determining the optimal health and development of infants, and is associated with a decreased risk for many early life diseases and conditions, including otitis media, respiratory tract infection, Diarrhea and early childhood obesity [3].

It is estimated that sub-optimal breastfeeding, especially non-exclusive breastfeeding in the first 6 months of life, results in 1.4 million deaths and $10 \%$ of the disease burden in children younger than 5 years of age [4]. EBF reduces infant mortality rates by up to $13 \%$ in low-income countries [5]. Some African countries like Nigeria and Ghana have established the Baby-Friendly Hospital Initiative (BFHI) with the aim of providing mothers and their infants a supportive environment for breastfeeding and to promote appropriate breastfeeding practices, thus helping to reduce infant morbidity and mortality rates [6].

Numerous variables may influence breastfeeding such as race, politics, maternal age, maternal employment, level of education of parents, socio-economic status, insufficient milk supply, infant health problems, maternal obesity, smoking, parity, method of delivery, maternal interest and other related factors, Some researchers have proposed that lack of suitable facilities outside of the home, inconveniences; conflicts at work, family pressure and ignorance adversely affect the willingness of women to practice EBF [7].The need to return to work has also been implicated as a factor interfering with EBF [8]. In late 1900s Breastfeeding was discovered to have unrecognized emotional and health benefits for baby and mothers [9] also contains all the nutrients that an infant needs in the first 6 months of life, including fat, carbohydrates, proteins, vitamins, minerals and water $[10,11]$. It is easily digested and efficiently used. Breast milk also contains bioactive factors that augment the infant's immature immune system, providing protection against infection, and other factors that help digestion and absorption of nutrients. Powdered infant formula it may be unsafe in other ways. Life threatening infections in newborns have been traced to contamination with pathogenic bacteria, such as Entero bacterial sakazakii, found in powdered formula [12]. Soy formula contains phyto-oestrogens, with activity similar to the human hormone Oestrogen, which could potentially reduce fertility in boys and bring early puberty in girls when the oxytocin reflex is active, there for breastfeeding helps prevent growth faltering and stunting, particularly as it reduces the risk of illnesses [13]. Breastfeeding protects against weight loss due to diarrhea, and in some studies children exclusively breastfed were shown to be less likely to be stunted [14]. Due to its large impact on reduction of infectious diseases, breastfeeding plays a role in reduction of stunting, as infectious diseases are important determinants of stunting. However, breastfed children will still become stunted if they do not receive an adequate quantity and quality of complementary foods from the age of six months onwards [15]. A more detailed understanding of the attitude of mothers to EBF and their knowledge of the importance of breastfeeding in South Sudan is needed to develop 


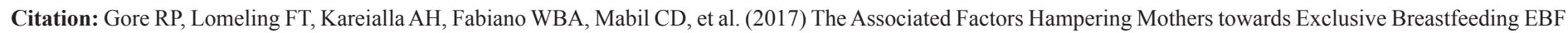
through Knowledge, Attitude and Practice (KAP) Studies at Al-Sabah Children Hospital/Juba -South Sudan. J Community Med Public Health : CMPH-101.

effective interventions to improve the rates of EBF and thus reduce infant mortality rate that is the highest in the World.

\section{Scope of the problem}

Data suggest that infant mortality in developing countries is 5-10 times higher among children who have not been breastfed or who have been breastfed for less than six months. It is estimated that some optimal breastfeeding especially non-exclusive breastfeeding in the first six months of live results in 1.4 Million deaths and $10 \%$ of disease burden in children younger than five years [16]. The Global Strategy for Infant and Young Child Feeding, according to WHO, two-thirds of under-five deaths that occur in infancy are mostly related to poor feeding practices. Globally, less than $40 \%$ of infants under six months of age are exclusively breastfed, despite the well documented benefits of breastfeeding [17]. In developing countries only $38 \%$ of infants aged less than six months are exclusively breastfed [18]. According to the 2010 Sudan household survey only $45 \%$ of the babies in Southern Sudan are exclusively breastfed for the first six months of life. On a press report released by UNCIEF on the breastfeeding week, 1-7, August 2013, they said most mothers in South Sudan do not breastfeed their children exclusively because of inadequate information on the importance of early initiation and EBF, inadequate support from families and communities, lack of counseling to new mothers on breastfeeding and heavy workload that keeps them away from their children for long hours [19].

\section{Statement of the problem}

One of the biggest threats to infant feeding is complacency. With competing priorities, disease specific funding, and interest in technologies, campaigns and products, the attention breastfeeding receives is very small, given the magnitude of the problem and the potential impact. Working mothers are kept away from their children by the schedules of their long working hours and hence have limited time to nurture their babies properly aggravate poor attitude towards breastfeeding. Breastfeeding has economic benefits, is also the least expensive. For many poor households, the high cost of breast milk substitutes, feeding and sterilizing equipment, fuel, represents a drain on scarce household resources. Plus cost of health care for the sick infant.

\section{Justification for the Study}

The study is being conducted to encourage and influence the attitude of EBF practices which count on awareness on importance of EBF, breast milk is the adequate 'baby food' that contains sufficient nutritional contents necessary for the growing of healthy babies, non-practice of EBF complicate the healthy growth of infants.

Goal: To ensure that every mother in South Sudan value the importance of EBF for the optimal growth, survival and development of healthy infants.
General Objective: To assess the related factors hindering mother's knowledge, attitude and practices towards exclusive breastfeeding of infants in Juba.

\section{Specific Aims:}

- To determine the prevalence of EBF in Juba / South Sudan.

- To evaluate pattern of Exclusive Breastfeeding (EBF) among lactating mothers attending Al-Sabah Children Hospital.

- To compare exclusive breastfeeding between working and non-working mothers.

- To identify the major problems hindering EBF among the study group.

- To identify the relationship between the age of mother and the attitude to breastfeeding of infants.

\section{Research hypothesis}

- $\quad$ Educated mothers tend to exclusively breastfeed their infants more than the uneducated mothers.

- Mothers who attend ANC are more likely to exclusively breastfeed compared to those who do not attend.

- Elderly Mothers exclusively breastfeed Infants more than young breastfeeding mothers in Juba.

\section{Methodology}

\section{Study design and data collection}

A questionnaire-based qualitative study was conducted on a group of 123 nursing mothers from December 2013 to 30th June 2014 to elicit information about knowledge attitude and practice towards EBF by using a properly designed questionnaire given to Breastfeeding mothers at Al-Sabah children Hospital in Juba.

\section{Study Area}

Al-Sabbah Children Hospital was established in 1983-1984 through the support of Kuwait government to the people of Southern Region (former Sudan). It is located opposite All Saints Cathedral on the way from Juba Teaching Hospital on the right side after Mobil roundabout. The Hospital was under the administration of the Islamic Organization until 2005, when the management was handed over to Central Equatoria Government (CEG). The hospital is made up of five departments with five medical officers. It daily receives 100-150 outpatients at the Clinic because it is the only Children Hospital in Juba County and has inpatient capacity of one hundred (100) m beds only.

\section{Population, Sample size and Sampling technique}

The sample size was one hundred and twenty-three (123) participants selected randomly from the population of breastfeeding mothers attending clinics at the Hospital. These mothers come from different Payams (Districts) of Juba County. 


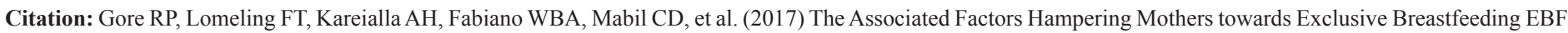
through Knowledge, Attitude and Practice (KAP) Studies at Al-Sabah Children Hospital/Juba -South Sudan. J Community Med Public Health : CMPH-101.

\section{The Duration of Study}

December 2013 to 30th June 2014.

Questionnaire design: The questionnaire consisted primarily of closed and open ended questions format and multiple responses for ease of completion and analysis. A structured questionnaire was self-administered by literate mothers and interviewer-administered for those who were illiterate. The resulting questionnaire consisted of 25 questions, categorized on two sections:

- Background information on the mother's demography that includes age, Education, marital status, occupation, residence, Religion, chronic illness, ANC visits.

- Background of the child which includes sex, date of birth (age), other children $<2$ years and elderly people at home, whether mothers breastfeeds or not and why not? commencement of other foods, breastfeeding initiation, duration of EBF, attitude on EBF sum of time spent on breastfeeding and breastfeeding interference with work productivity, breastfeeding in public places, and immunity.

The subjects: The sample of the nursing mothers' population consisting of mothers aged 16 to above 45 years who were nursing their infants six months and below participated in the study.

\section{Inclusion and exclusion criteria}

- Inclusion criteria; mothers who have already delivered their baby and the child is between 0-6 month of age were considered in this study.

- Exclusion Criteria: Pregnant mothers or mothers with children who are above six months of age.

\section{Data Analysis}

The questionnaire responses were collected and analyzed using Statistical Package for Social Scientist (SPSS) version 16.0. Chi-square tests were used to evaluate relationship between different selected variables (e.g. find association between level of education and EBF, Age of mother and attitude to EBF). The critical value for significance was set at $\mathrm{P}<0.05$ for all analyses. The findings were presented in tables and pie charts.

\section{Ethical Considerations}

Researchers were granted approval by the University of Juba, Department of Community Medicine, and prior consents were obtained from the Hospital Chief Executive Officer (CEO) and all participants who took part in the study.

\section{Results}

According to the study, $54.5 \%$ of breastfeeding mothers were in the age range $16-25,40.7 \%$ of the mothers were of age range $26-35 \mathrm{yrs}$ and finally $4 \%$ were in the range $36-45 \mathrm{yrs}$ as shown in the (Table 1)

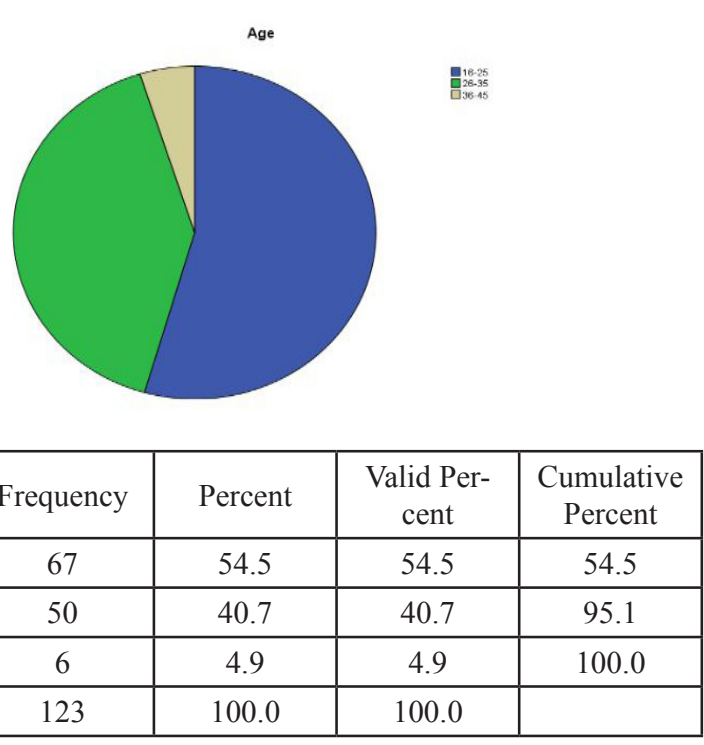

Table 1: Age Group of breastfeeding mothers in Juba from Dec 2013-Jun 2014.

Based on the educational level $38.2 \%$ attended basic education, $19.5 \%$ attended secondary, $7.3 \%$ attended university and $35 \%$ never attend any formal education in average $65 \%$ of the breastfeeding mothers attended formal education (Table 2)

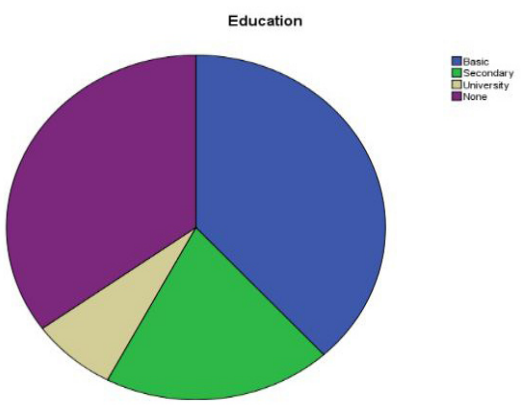

\begin{tabular}{|c|c|c|c|c|}
\hline & Frequency & Percent & $\begin{array}{c}\text { Valid Per- } \\
\text { cent }\end{array}$ & $\begin{array}{c}\text { Cumulative } \\
\text { Percent }\end{array}$ \\
\hline Basic & 47 & 38.2 & 38.2 & 38.2 \\
\hline Secondary & 24 & 19.5 & 19.5 & 57.7 \\
\hline University & 9 & 7.3 & 7.3 & 65.0 \\
\hline None & 43 & 35.0 & 35.0 & 100.0 \\
\hline Total & 123 & 100.0 & 100.0 & \\
\hline & & & & \\
\hline
\end{tabular}

Table 2: Education level of breastfeeding mothers in Juba from Dec 2013Jun 2014.

The study shows that $2.4 \%$ were single mothers, $92.7 \%$ were married, $4.1 \%$ divorced/ separated and only $0.8 \%$ widower. (Table 3 ) 


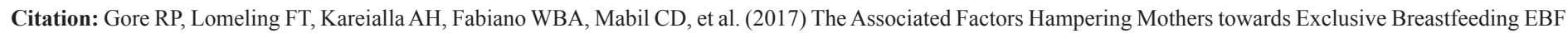
through Knowledge, Attitude and Practice (KAP) Studies at Al-Sabah Children Hospital/Juba -South Sudan. J Community Med Public Health : CMPH-101.

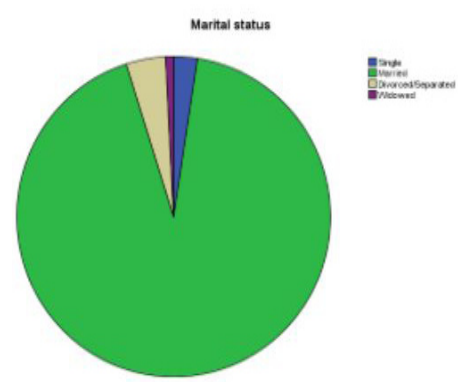

\begin{tabular}{|c|c|c|c|c|}
\hline & $\begin{array}{c}\text { Fre- } \\
\text { quency }\end{array}$ & Percent & $\begin{array}{c}\text { Valid Per- } \\
\text { cent }\end{array}$ & $\begin{array}{c}\text { Cumulative } \\
\text { Percent }\end{array}$ \\
\hline Single & 3 & 2.4 & 2.4 & 2.4 \\
\hline Married & 114 & 92.7 & 92.7 & 95.1 \\
\hline $\begin{array}{c}\text { Divorced/Sepa- } \\
\text { rated }\end{array}$ & 5 & 4.1 & 4.1 & 99.2 \\
\hline Widowed & 1 & .8 & .8 & 100.0 \\
\hline Total & 123 & 100.0 & 100.0 & \\
\hline
\end{tabular}

Table 3: Marital status of breastfeeding mothers in Juba from Dec 2013Jun 2014.

Exploring the income of the study group, the study reveals that $8.1 \%$ were self-employed, $12.2 \%$ employed both in private and public sector, $79.7 \%$ were unemployed (Table 4)
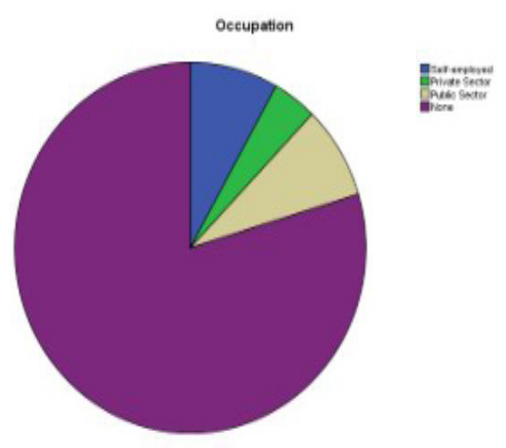

\begin{tabular}{|c|c|c|c|c|}
\hline & $\begin{array}{c}\text { Frequen- } \\
\text { cy }\end{array}$ & Percent & $\begin{array}{c}\text { Valid Per- } \\
\text { cent }\end{array}$ & $\begin{array}{c}\text { Cumulative } \\
\text { Percent }\end{array}$ \\
\hline Self-employed & 10 & 8.1 & 8.1 & 8.1 \\
\hline Private Sector & 5 & 4.1 & 4.1 & 12.2 \\
\hline Public Sector & 10 & 8.1 & 8.1 & 20.3 \\
\hline None & 98 & 79.7 & 79.7 & 100.0 \\
\hline Total & 123 & 100.0 & 100.0 & \\
\hline
\end{tabular}

Table 4: Occupation of nursing mothers in Juba from Dec 2013-Jun 2014.

According to the study $22.0 \%$ of the mothers were from Juba Payam, 26.0\% were from Kator Payam, 43.2\% were from Munuki Payam, and 9.7\% were from Rajaf Payam (Table 5)
Residence of mother in Juba from Dec 2013-Jun 2014

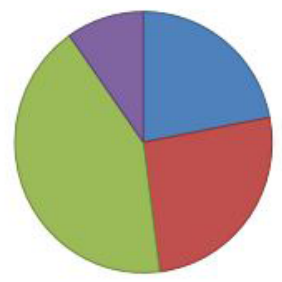

\begin{tabular}{|c|c|c|c|c|}
\hline Payam & Frequency & Percent & $\begin{array}{c}\text { Valid Per- } \\
\text { cent }\end{array}$ & $\begin{array}{c}\text { Cumulative } \\
\text { Percent }\end{array}$ \\
\hline Juba & 27 & 22.0 & 22.0 & 22.0 \\
\hline Kator & 32 & 26.0 & 26.0 & 48.0 \\
\hline Munuki & 52 & 42.3 & 42.3 & 90.3 \\
\hline Rajaf & 12 & 9.7 & 9.7 & 100.0 \\
\hline Total & 123 & 100.0 & 100.0 & \\
\hline
\end{tabular}

Table 5: Residence of mothers in Juba city from Dec 2013-Jun 2014.

In context of the religion, majority about $93.5 \%$ were Christian, $5.7 \%$ were Muslim and $0.8 \%$ were non none religious (Table 6 )

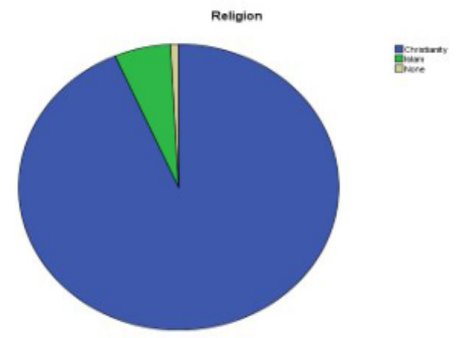

\begin{tabular}{|c|c|c|c|c|}
\hline & Frequency & Percent & $\begin{array}{c}\text { Valid Per- } \\
\text { cent }\end{array}$ & $\begin{array}{c}\text { Cumulative } \\
\text { Percent }\end{array}$ \\
\hline Christianity & 115 & 93.5 & 93.5 & 93.5 \\
\hline Islam & 7 & 5.7 & 5.7 & 99.2 \\
\hline None & 1 & .8 & .8 & 100.0 \\
\hline Total & 123 & 100.0 & 100.0 & \\
\hline
\end{tabular}

Table 6: Religion of nursing mothers in Juba from Dec 2013-Jun 2014.

In term of chronic illness, only $8.1 \%$ had while about $91.9 \%$ never had any chronic diseases according to the report (Table 7).

\begin{tabular}{|c|c|c|c|c|}
\hline & Frequency & Percent & $\begin{array}{c}\text { Valid Per- } \\
\text { cent }\end{array}$ & $\begin{array}{c}\text { Cumulative } \\
\text { Percent }\end{array}$ \\
\hline Yes & 10 & 8.1 & 8.1 & 8.1 \\
\hline No & 113 & 91.9 & 91.9 & 100.0 \\
\hline Total & 123 & 100.0 & 100.0 & \\
\hline
\end{tabular}

Table 7: Cases of Chronic Illness among breastfeeding mothers in Juba from Dec 2013- Jun 2014. 


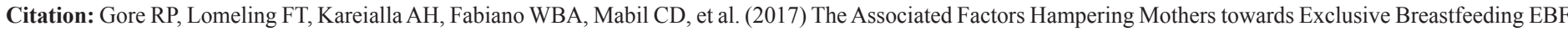
through Knowledge, Attitude and Practice (KAP) Studies at Al-Sabah Children Hospital/Juba -South Sudan. J Community Med Public Health : CMPH-101.

In regards to ANC visits it shows that $77.2 \%$ regularly attended, $11.4 \%$ irregularly attended, $10.6 \%$ of no ANC attended, and $0.8 \%$ do not know (Table 8 )

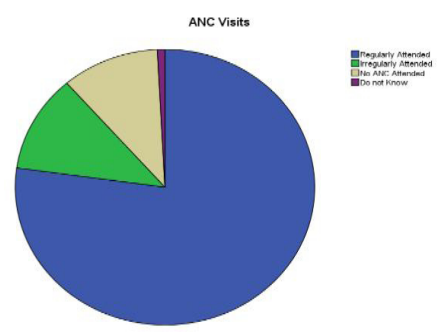

\begin{tabular}{|c|c|c|c|c|}
\hline & $\begin{array}{c}\text { Fre- } \\
\text { quency }\end{array}$ & Percent & $\begin{array}{c}\text { Valid Per- } \\
\text { cent }\end{array}$ & $\begin{array}{c}\text { Cumulative } \\
\text { Percent }\end{array}$ \\
\hline $\begin{array}{c}\text { Regularly At- } \\
\text { tended }\end{array}$ & 95 & 77.2 & 77.2 & 77.2 \\
\hline $\begin{array}{c}\text { Irregularly At- } \\
\text { tended }\end{array}$ & 14 & 11.4 & 11.4 & 88.6 \\
\hline No ANC Attended & 13 & 10.6 & 10.6 & 99.2 \\
\hline Do not Know & 1 & .8 & .8 & 100.0 \\
\hline Total & 123 & 100.0 & 100.0 & \\
\hline
\end{tabular}

Table 8: Responses of breastfeeding mothers to ANC Visits in Juba from Dec 2013- Jun 2014.

\begin{tabular}{|c|c|c|c|c|}
\hline & Frequency & Percent & $\begin{array}{c}\text { Valid Per- } \\
\text { cent }\end{array}$ & $\begin{array}{c}\text { Cumulative } \\
\text { Percent }\end{array}$ \\
\hline Male & 63 & 51.2 & 51.2 & 51.2 \\
\hline Female & 60 & 48.8 & 48.8 & 100.0 \\
\hline Total & 123 & 100.0 & 100.0 & \\
\hline
\end{tabular}

Table 9: Sex of breastfed infants at Al-Sabah Hospital in Juba from Dec 2013-Jun 2014

The target groups of infants in the study were of age ranging 1 day-6months. The study shows that majority about $35.8 \%$ infants were born in Dec 2013, from June 2014 the percentage was 64.2\% (Table 10)

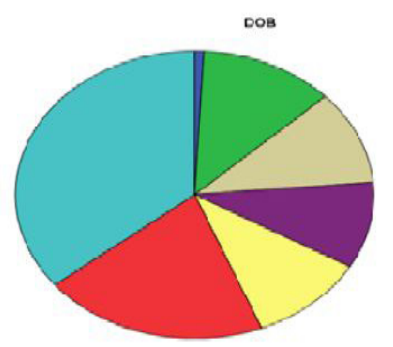

\begin{tabular}{|c|c|c|c|c|}
\hline & Frequency & Percent & $\begin{array}{c}\text { Valid Per- } \\
\text { cent }\end{array}$ & $\begin{array}{c}\text { Cumulative } \\
\text { Percent }\end{array}$ \\
\hline Jun & 1 & .8 & .8 & .8 \\
\hline May & 15 & 12.2 & 12.2 & 13.0 \\
\hline Apr & 13 & 10.6 & 10.6 & 23.6 \\
\hline Mar & 12 & 9.8 & 9.8 & 33.3 \\
\hline Feb & 13 & 10.6 & 10.6 & 43.9 \\
\hline Jan & 25 & 20.3 & 20.3 & 64.2 \\
\hline Dec & 44 & 35.8 & 35.8 & 100.0 \\
\hline Total & 123 & 100.0 & 100.0 & \\
\hline
\end{tabular}

Table 10: Month of Birth (age) of infants in Juba from Dec 2013-Jun 2014.

Immunization status of the infant; the finding reveal that, majority $80.5 \%$ were immunized with $19.5 \%$ of the infant not given any vaccine (Table 11)

\begin{tabular}{|c|c|c|c|c|}
\hline & Frequency & Percent & $\begin{array}{c}\text { Valid Per- } \\
\text { cent }\end{array}$ & $\begin{array}{c}\text { Cumulative } \\
\text { Percent }\end{array}$ \\
\hline no & 24 & 19.5 & 19.5 & 19.5 \\
\hline yes & 99 & 80.5 & 80.5 & 100.0 \\
\hline Total & 123 & 100.0 & 100.0 & \\
\hline
\end{tabular}

Table 11: Possession of Immunization Card by infants in Juba from Dec 2013-Jun 2014.

Having dependent or other people at the home; it was found that $16.3 \%$ had other infants at their homes, $19.5 \%$ of the respondents had children of less than two years of age at their home, $21.1 \%$ had adults greater than sixty years old and $43.1 \%$ had no any other departments in their homes (Table 12)

\begin{tabular}{|c|c|c|c|c|}
\hline & $\begin{array}{c}\text { Fre- } \\
\text { quency }\end{array}$ & Percent & $\begin{array}{c}\text { Valid Per- } \\
\text { cent }\end{array}$ & $\begin{array}{c}\text { Cumulative } \\
\text { Percent }\end{array}$ \\
\hline Infants & 20 & 16.3 & 16.3 & 16.3 \\
\hline Children<2yrs & 24 & 19.5 & 19.5 & 35.8 \\
\hline Adults>60yrs & 26 & 21.1 & 21.1 & 56.9 \\
\hline None & 53 & 43.1 & 43.1 & 100.0 \\
\hline Total & 123 & 100.0 & 100.0 & \\
\hline
\end{tabular}

Table 12: Other Dependents in the house of nursing mothers in Juba from Dec 2013-Jun 2014.

\section{Breastfeeding Practice}

A high level of Breastfeeding practice exists in the study group with $96.7 \%$ breastfeeding according to respondents; only $3.3 \%$ of the women were not practicing breastfeeding. (Table 13) 


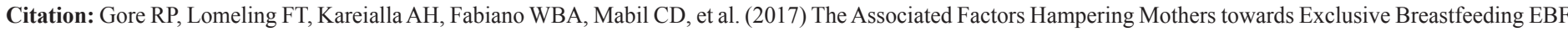
through Knowledge, Attitude and Practice (KAP) Studies at Al-Sabah Children Hospital /Juba -South Sudan. J Community Med Public Health : CMPH-101.

\begin{tabular}{|c|c|c|c|c|}
\hline & Frequency & Percent & $\begin{array}{c}\text { Valid Per- } \\
\text { cent }\end{array}$ & $\begin{array}{c}\text { Cumulative } \\
\text { Percent }\end{array}$ \\
\hline no & 5 & 4.1 & 4.1 & 4.1 \\
\hline yes & 118 & 95.9 & 95.9 & 100.0 \\
\hline Total & 123 & 100.0 & 100.0 & \\
\hline
\end{tabular}

\begin{tabular}{|c|c|c|c|c|}
\hline After 6 months & 38 & 30.9 & 30.9 & 91.1 \\
\hline Don't know & 11 & 8.9 & 8.9 & 100.0 \\
\hline Total & 123 & 100.0 & 100.0 & \\
\hline
\end{tabular}

Table 16: Initiation of complementary foods to Infants in Juba from Dec 2013-June 2014.

Table 13: Breastfeeding Infants (Yes/No) in Juba from Dec 2013-Jun 2014.

For those who were breastfeeding, 59.3\%were breastfed 8 times or more. $11.8 \%$ breastfed less than 8 times, $26.0 \%$ do not know the number of times they breastfeed their infant and $3.3 \%$ were not breastfeed (Table 14)

\begin{tabular}{|c|c|c|c|c|}
\hline & Frequency & Percent & $\begin{array}{c}\text { Valid Per- } \\
\text { cent }\end{array}$ & $\begin{array}{c}\text { Cumulative } \\
\text { Percent }\end{array}$ \\
\hline no & 5 & 4.1 & 4.1 & 4.1 \\
\hline yes & 118 & 95.9 & 95.9 & 100.0 \\
\hline Total & 123 & 100.0 & 100.0 & \\
\hline
\end{tabular}

Table 14: Breastfeeding Infants (Yes/No) in Juba from Dec 2013-Jun 2014.

\section{Reasons for not Breastfeeding}

The following were the reasons given by the mothers of the $3.3 \%$ of infants who were not breastfeed; abandonment by the mother $(0.8 \%)$, breast lump(swelling) $0.8 \%$, no enough milk $(0.8 \%)$, and oral candidiasis $(0.8 \%)$ (Table 15$)$

\begin{tabular}{|c|c|c|c|c|}
\hline & $\begin{array}{c}\text { Fre- } \\
\text { quency }\end{array}$ & Percent & $\begin{array}{c}\text { Valid } \\
\text { Percent }\end{array}$ & $\begin{array}{c}\text { Cumulative } \\
\text { Percent }\end{array}$ \\
\hline Breastfeeding & 119 & 96.7 & 96.7 & 96.7 \\
\hline $\begin{array}{c}\text { Abandon by } \\
\text { mother }\end{array}$ & 1 & .8 & .8 & 97.6 \\
\hline Breast lump & 1 & .8 & .8 & 98.4 \\
\hline No enough BM & 1 & .8 & .8 & 99.2 \\
\hline Oral candidacies & 1 & .8 & .8 & 100.0 \\
\hline Total & 123 & 100.0 & 100.0 & \\
\hline
\end{tabular}

Table 15: Reasons for not breastfeeding infant in Juba from Dec 2013Jun 2014.

According to our finding $30.1 \%$ of the infants were breastfed 2-10 times, $15.4 \%$ were breastfed $11-20$ times, $51.2 \%$ do not know the number of times their infant breastfed and finally $3.3 \%$ were not breastfed completely (Table 16)

\begin{tabular}{|c|c|c|c|c|}
\hline & $\begin{array}{c}\text { Fre- } \\
\text { quency }\end{array}$ & Percent & $\begin{array}{c}\text { Valid Per- } \\
\text { cent }\end{array}$ & $\begin{array}{c}\text { Cumulative } \\
\text { Percent }\end{array}$ \\
\hline Before 4 months & 28 & 22.8 & 22.8 & 22.8 \\
\hline $\begin{array}{c}\text { Between 4 \& 6 } \\
\text { months }\end{array}$ & 46 & 37.4 & 37.4 & 60.2 \\
\hline
\end{tabular}

\begin{tabular}{|c|c|c|c|c|}
\hline & $\begin{array}{c}\text { Fre- } \\
\text { quency }\end{array}$ & Percent & $\begin{array}{c}\text { Valid Per- } \\
\text { cent }\end{array}$ & $\begin{array}{c}\text { Cumulative } \\
\text { Percent }\end{array}$ \\
\hline Before 4 months & 28 & 22.8 & 22.8 & 22.8 \\
\hline $\begin{array}{c}\text { Between 4 \& 6 } \\
\text { months }\end{array}$ & 46 & 37.4 & 37.4 & 60.2 \\
\hline After 6 months & 38 & 30.9 & 30.9 & 91.1 \\
\hline Don't know & 11 & 8.9 & 8.9 & 100.0 \\
\hline Total & 123 & 100.0 & 100.0 & \\
\hline
\end{tabular}

Table 17: Initiation of complementary foods to Infants in Juba from Dec 2013-June 2014.

\section{Exclusive Breastfeeding Practices}

$35 \%$ exclusively breastfed, $14.7 \%$ were given juice and water, $4.9 \%$ were given soup and $45.5 \%$ were given others foods. (Table 18)

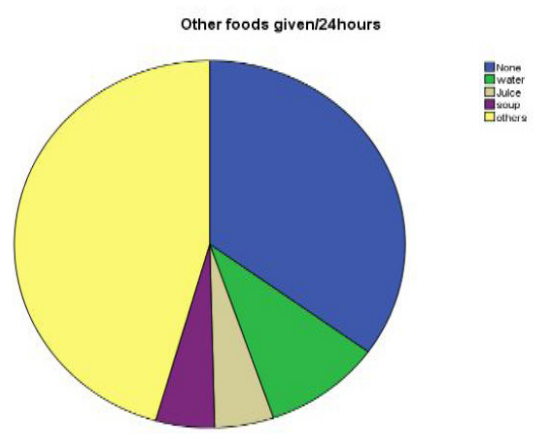




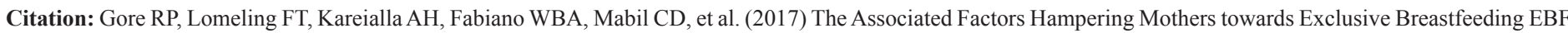
through Knowledge, Attitude and Practice (KAP) Studies at Al-Sabah Children Hospital/Juba -South Sudan. J Community Med Public Health : CMPH-101.

\begin{tabular}{|c|c|c|c|c|}
\hline & Frequency & Percent & $\begin{array}{c}\text { Valid Per- } \\
\text { cent }\end{array}$ & $\begin{array}{c}\text { Cumulative } \\
\text { Percent }\end{array}$ \\
\hline None & 43 & 35.0 & 35.0 & 35.0 \\
\hline water & 12 & 9.8 & 9.8 & 44.7 \\
\hline Juice & 6 & 4.9 & 4.9 & 49.6 \\
\hline soup & 6 & 4.9 & 4.9 & 54.5 \\
\hline others & 56 & 45.5 & 45.5 & 100.0 \\
\hline Total & 123 & 100.0 & 100.0 & \\
\hline
\end{tabular}

Table 18: Other fluids or foods given to infant /last 24hours in Juba from Dec 2013-Jun 2014.

\section{Start of Breastfeeding}

The knowledge of mothers about the initiation time for breastfeeding was tested and the responses were as follows; $66.2 \%$ immediately after birth, $20.3 \%$ within hours, $13.8 \%$ within days and $3.3 \%$ do not know the time for initiation of breastfeeding (Table 19)
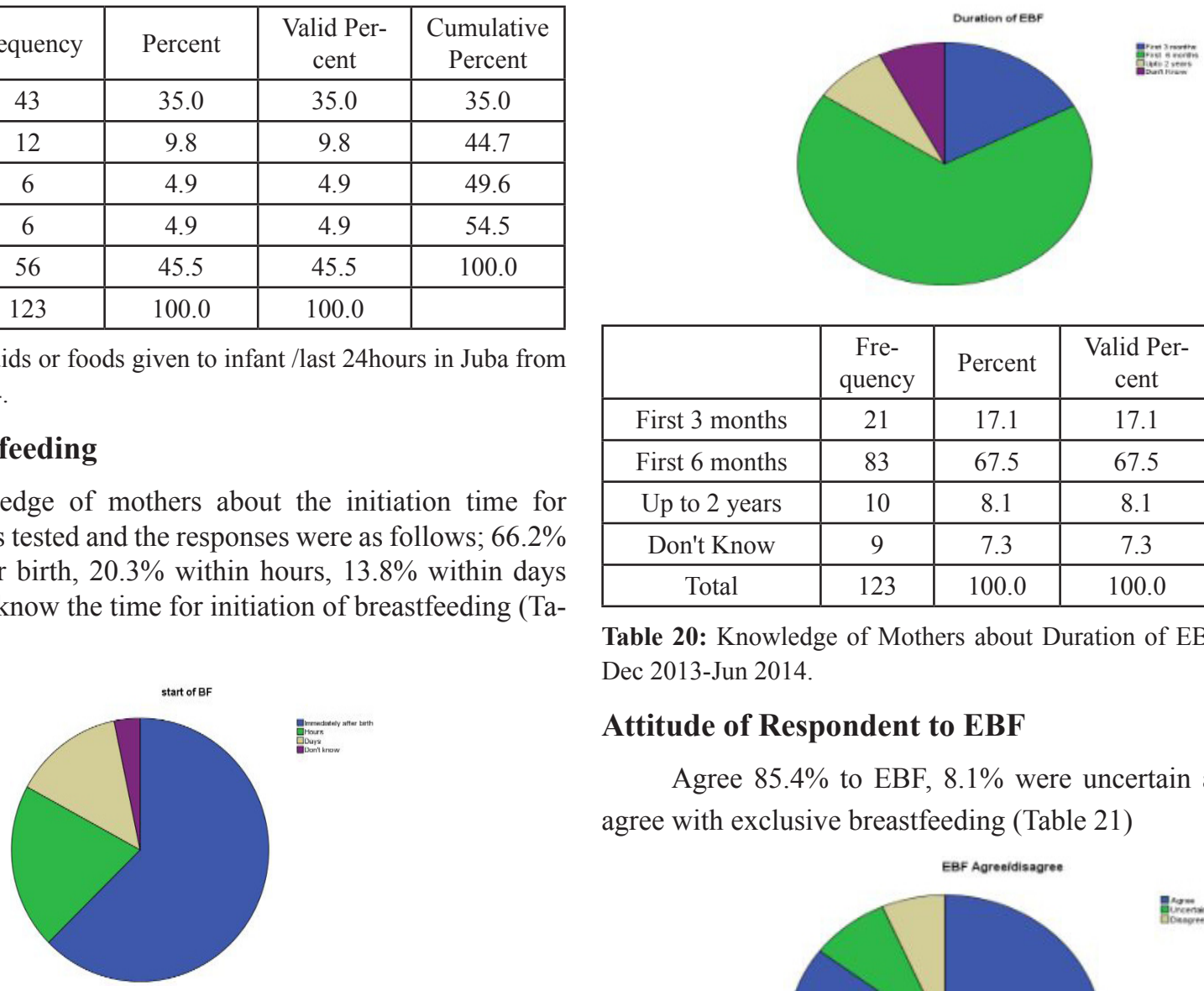

\begin{tabular}{|c|c|c|c|c|}
\hline & $\begin{array}{c}\text { Fre- } \\
\text { quency }\end{array}$ & Percent & $\begin{array}{c}\text { Valid Per- } \\
\text { cent }\end{array}$ & $\begin{array}{c}\text { Cumulative } \\
\text { Percent }\end{array}$ \\
\hline First 3 months & 21 & 17.1 & 17.1 & 17.1 \\
\hline First 6 months & 83 & 67.5 & 67.5 & 84.6 \\
\hline Up to 2 years & 10 & 8.1 & 8.1 & 92.7 \\
\hline Don't Know & 9 & 7.3 & 7.3 & 100.0 \\
\hline Total & 123 & 100.0 & 100.0 & \\
\hline
\end{tabular}

Table 20: Knowledge of Mothers about Duration of EBF in Juba from Dec 2013-Jun 2014.

\section{Attitude of Respondent to EBF}

Agree $85.4 \%$ to EBF, $8.1 \%$ were uncertain and $6.5 \%$ disagree with exclusive breastfeeding (Table 21)

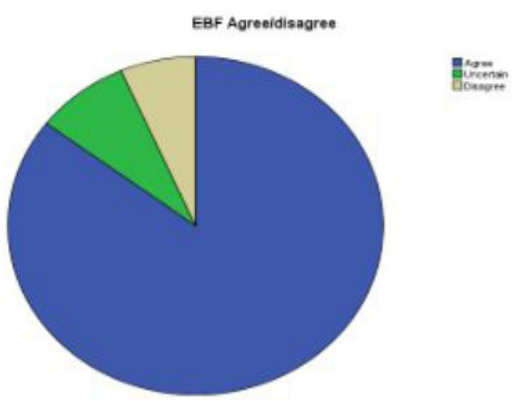

\begin{tabular}{|c|c|c|c|c|}
\hline & $\begin{array}{c}\text { Fre- } \\
\text { quency }\end{array}$ & Percent & $\begin{array}{c}\text { Valid } \\
\text { Percent }\end{array}$ & $\begin{array}{c}\text { Cumu- } \\
\text { lative } \\
\text { Percent }\end{array}$ \\
\hline $\begin{array}{c}\text { Immediately after } \\
\text { birth }\end{array}$ & 77 & 62.6 & 62.6 & 62.6 \\
\hline Hours & 25 & 20.3 & 20.3 & 82.9 \\
\hline Days & 17 & 13.8 & 13.8 & 96.7 \\
\hline Don't know & 4 & 3.3 & 3.3 & 100.0 \\
\hline Total & 123 & 100.0 & 100.0 & \\
\hline
\end{tabular}

Table 19: Knowledge of mothers about starting of Breastfeeding of their infants in Juba from Dec 2013-Jun 2014.

\section{Duration of EBF}

Responses to the participants' knowledge were $17.1 \%$ first three months, $67.5 \%$ first six months, $8.1 \%$ up-to two years and $7.3 \%$ do not know for how long the exclusivity of breastfeeding should be practiced (Table 20)

\begin{tabular}{|c|c|c|c|c|}
\hline & Frequency & Percent & $\begin{array}{c}\text { Valid Per- } \\
\text { cent }\end{array}$ & $\begin{array}{c}\text { Cumulative } \\
\text { Percent }\end{array}$ \\
\hline Agree & 105 & 85.4 & 85.4 & 85.4 \\
\hline Uncertain & 10 & 8.1 & 8.1 & 93.5 \\
\hline Disagree & 8 & 6.5 & 6.5 & 100.0 \\
\hline Total & 123 & 100.0 & 100.0 & \\
\hline
\end{tabular}

Table 21: Attitude of others towards EBF in Juba from Dec 2013-Jun 2014.

Time spent breastfeeding and its interference with work productivity: $27.6 \%$ of the women agree that time spent breastfeeding at work should not be paid but $73.4 \%$ disagree with not paying the time the mother spent breastfeeding at work place (Table 22) 


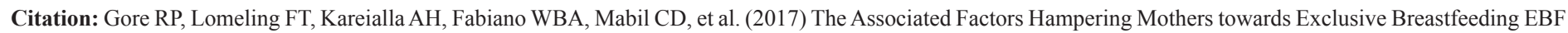
through Knowledge, Attitude and Practice (KAP) Studies at Al-Sabah Children Hospital/Juba -South Sudan. J Community Med Public Health : CMPH-101.

\begin{tabular}{|c|c|c|c|c|}
\hline & Frequency & Percent & $\begin{array}{c}\text { Valid Per- } \\
\text { cent }\end{array}$ & $\begin{array}{c}\text { Cumulative } \\
\text { Percent }\end{array}$ \\
\hline Agree & 34 & 27.6 & 27.6 & 27.6 \\
\hline Disagree & 89 & 72.4 & 72.4 & 100.0 \\
\hline Total & 123 & 100.0 & 100.0 & \\
\hline
\end{tabular}

Table 22: Attitude of Mothers towards Payment of the time spent in Breastfeeding in Juba from Dec 2013-Jun 2104.

\section{Whether Breastfeeding interferes with work Productivity}

$44.7 \%$ of the women consented that breastfeeding or expressing breast milk at work will interfere with work productivity while $55.3 \%$ said this practice does not interfere with work productivity at all (Table 23)

\begin{tabular}{|c|c|c|c|c|}
\hline & Frequency & Percent & $\begin{array}{c}\text { Valid Per- } \\
\text { cent }\end{array}$ & $\begin{array}{c}\text { Cumulative } \\
\text { Percent }\end{array}$ \\
\hline Yes & 55 & 44.7 & 44.7 & 44.7 \\
\hline No & 68 & 55.3 & 55.3 & 100.0 \\
\hline Total & 123 & 100.0 & 100.0 & \\
\hline
\end{tabular}

Table 23: Whether Breastfeeding interferes with work Productivity in Juba from Dec 2013-Jun 2104.

Breastfeeding in public places: $65 \%$ of the mothers agree that the baby can be fed anywhere whenever it feels hungry, $8.1 \%$ were uncertain and $39.0 \%$ disagree with breastfeeding their baby in public places (Table 24)

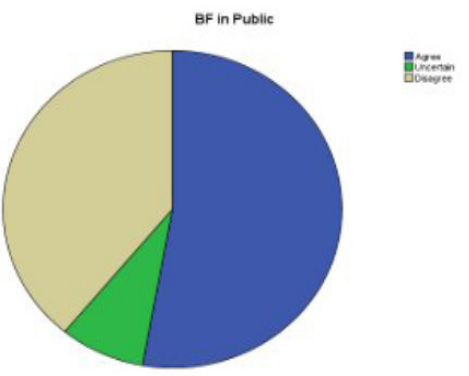

\begin{tabular}{|c|c|c|c|c|}
\hline & Frequency & Percent & $\begin{array}{c}\text { Valid Per- } \\
\text { cent }\end{array}$ & $\begin{array}{c}\text { Cumulative } \\
\text { Percent }\end{array}$ \\
\hline Agree & 65 & 52.8 & 52.8 & 52.8 \\
\hline Uncertain & 10 & 8.1 & 8.1 & 61.0 \\
\hline Disagree & 48 & 39.0 & 39.0 & 100.0 \\
\hline Total & 123 & 100.0 & 100.0 & \\
\hline
\end{tabular}

Table 24: Attitude of mothers towards Breastfeeding in Public places in Juba from Dec 2013-Jun 2014.

Knowledge about immunity when breastfeeding infant: $97.6 \%$ of the mothers have the knowledge that the immune system of breastfed infant is stronger than formula-fed infant, only $2.4 \%$ do not know about this important fact (Table 25)

\begin{tabular}{|c|c|c|c|c|}
\hline & Frequency & Percent & $\begin{array}{c}\text { Valid Per- } \\
\text { cent }\end{array}$ & $\begin{array}{c}\text { Cumulative } \\
\text { Percent }\end{array}$ \\
\hline True & 120 & 97.6 & 97.6 & 97.6 \\
\hline False & 3 & 2.4 & 2.4 & 100.0 \\
\hline Total & 123 & 100.0 & 100.0 & \\
\hline
\end{tabular}

Table 25: Knowledge of Mothers about the strong Immune system of Breastfed infant compared to Formula-fed infants in Juba from Dec2103Jun 2014.

Education correlation with exclusive Breastfeeding: Basic $15.4 \%$, Secondary $6.5 \%$, University $3.3 \%$ exclusively breastfed and $9.8 \%$ of the non-educated mothers exclusively breastfed (Table 26)

\begin{tabular}{|c|c|c|c|c|c|c|}
\hline \multirow{2}{*}{$\begin{array}{c}\text { Educa- } \\
\text { tion } \\
\text { level }\end{array}$} & \multicolumn{5}{|c|}{ Other fluids given/24hours } & \multirow{2}{*}{ Total } \\
\cline { 2 - 6 } & None & water & Juice & soup & others & \\
\hline Basic & $15.40 \%$ & $4.10 \%$ & $1.60 \%$ & $1.60 \%$ & $15.40 \%$ & $38.20 \%$ \\
\hline $\begin{array}{c}\text { Second- } \\
\text { ary }\end{array}$ & $6.50 \%$ & $2.40 \%$ & & $0.80 \%$ & $9.80 \%$ & $19.50 \%$ \\
\hline $\begin{array}{c}\text { Univer- } \\
\text { sity }\end{array}$ & $3.30 \%$ & & $0.80 \%$ & & $3.30 \%$ & $7.30 \%$ \\
\hline None & $9.80 \%$ & $3.30 \%$ & $2.40 \%$ & $2.40 \%$ & $17.10 \%$ & $35.00 \%$ \\
\hline Total $\%$ & $35.00 \%$ & $9.80 \%$ & $4.90 \%$ & $4.90 \%$ & $45.50 \%$ & $100.00 \%$ \\
\hline
\end{tabular}

Table 26: Education other fluids given/24hours (EBF).

Antenatal Care (ANC) correlation with exclusive breastfeeding: Regularly attended $25.2 \%$, irregularly attended $6.5 \%$, No ANC attended $2.4 \%$, and $0.8 \%$ of the mothers who do not know ANC exclusively breastfed (Table 27)

\begin{tabular}{|c|c|c|c|c|c|c|}
\hline \multirow{2}{*}{ ANC Visits } & \multicolumn{5}{|c|}{ Other fluids given/24hours } & \multirow{2}{*}{ Total } \\
\cline { 2 - 6 } & None & water & Juice & soup & others & \\
\hline $\begin{array}{c}\text { Regularly } \\
\text { Attended }\end{array}$ & $25.20 \%$ & $8.10 \%$ & $1.60 \%$ & $4.90 \%$ & $37.40 \%$ & $77.20 \%$ \\
\hline $\begin{array}{c}\text { Irregularly } \\
\text { Attended }\end{array}$ & $6.50 \%$ & $0.80 \%$ & $0.80 \%$ & & $3.30 \%$ & $11.40 \%$ \\
\hline $\begin{array}{c}\text { No ANC } \\
\text { Attended }\end{array}$ & $2.40 \%$ & $0.80 \%$ & $2.40 \%$ & & $4.90 \%$ & $10.60 \%$ \\
\hline $\begin{array}{c}\text { Do not } \\
\text { Know }\end{array}$ & $0.80 \%$ & & & & & $0.80 \%$ \\
\hline Total \% & $35.00 \%$ & $9.80 \%$ & $4.90 \%$ & $4.90 \%$ & $45.50 \%$ & $100.00 \%$ \\
\hline
\end{tabular}

Table 27: ANC Visits other fluids given/24hours (EBF).

Age Correlation with exclusive breastfeeding: According to the findings $17.9 \%$ of the age group 16-25 exclusively breastfed their infants, $16.3 \%$ of the age group $26-35,0.8 \%$ of the age group 3645 exclusively breastfed their infants and there were no respondent in the age group above 45 (Table 28). 
Citation: Gore RP, Lomeling FT, Kareialla AH, Fabiano WBA, Mabil CD, et al. (2017) The Associated Factors Hampering Mothers towards Exclusive Breastfeeding EBF through Knowledge, Attitude and Practice (KAP) Studies at Al-Sabah Children Hospital/Juba -South Sudan. J Community Med Public Health : CMPH-101.

\begin{tabular}{|c|c|c|c|c|c|c|}
\hline \multirow{2}{*}{ Age group } & \multicolumn{5}{|c|}{ Other fluids given/24hours } & \multirow{2}{*}{ Total } \\
\cline { 2 - 6 } & None & water & Juice & soup & $26.80 \%$ & $54.50 \%$ \\
\hline $16-25$ & $17.90 \%$ & $4.90 \%$ & $2.40 \%$ & $2.40 \%$ & $15.40 \%$ & $40.70 \%$ \\
\hline $26-35$ & $16.30 \%$ & $4.10 \%$ & $2.40 \%$ & $2.40 \%$ & $3.30 \%$ & $4.90 \%$ \\
\hline $36-45$ & $0.80 \%$ & $0.80 \%$ & & & $45.50 \%$ & $100.00 \%$ \\
\hline Total $\%$ & $35.00 \%$ & $9.80 \%$ & $4.90 \%$ & $4.90 \%$ & $2 \%$ \\
\hline
\end{tabular}

Table 28: Age other fluids given/24hours (EBF).

\section{Discussion}

This study aimed to determine the prevalence of exclusive breastfeeding, knowledge, and attitude and associated factors affecting it. Ninety-seven percent of the mothers were practicing breastfeeding with only three percent who had not breastfed because of breast swelling, oral Candidiasis, scars breast milk and abandonment by the mother. This study revealed that the prevalence of exclusive breastfeeding practice for infant in their first six months of life was thirty- five percent $(35 \%)$, this finding is lower than the 2010 Sudan household survey which found out that forty-five percent of the babies in Southern Sudan were exclusively breastfed [19]. Our finding is much higher than in Lebanon (10\%), almost equal to Bangladesh (36\%) and lower than the exclusive breastfeeding prevalence in Ethiopia $(49 \%)(51,52)$. This decline in the trend of exclusive breastfeeding blamed is on the mothers not adhering strictly to the World Health Organization recommendation of EBF for the first six months. In addition to socio-cultural practices of early introduction of water, infant formula, soup, porridge and others before six months of age.

This is confounded by misleading advertisement of formula milk in the market which might have contributed negatively to exclusive breastfeeding. Although $67.5 \%$ of the participants had adequate knowledge on the definition of EBF, the practice was relatively lower (35.0\%) compared to the WHO recommendations for exclusive breastfeeding in developing countries. The average knowledge of the respondents about exclusive breastfeeding is about seventy-six $(76 \%)$.Our study participants highly valued the immune benefits of breastfeeding $97.6 \%$. It was found out that majority of the respondents had positive attitude towards exclusive breastfeeding $(85.4 \%)$ but only $33.4 \%$ of them exclusively breastfed.

We found that those participants who were mixed or formula feeding were more likely to have negative attitudes towards breastfeeding $(13.6 \%)$, including thinking that breastfeeding was embarrassing and difficult in public Places (39\%), it may be difficult if someone else feeds/cares for the child, and physically painful and uncomfortable and were likely to be influenced by the negative attitudes of family members or friends. Other studies that have evaluated the relationship between attitudes towards breastfeeding and breastfeeding intention have found that partner or friend/family support is important as is confidence or prior experience and fear of pain in deciding not to breastfeed. Mothers between the ages group 16-25 years showed the highest percentage (17.9\%) of exclusive breastfeeding in this study which was significantly $(p<0.05)$ different from mothers in the age group 26-35 years ( $16.3 \%$ ) and age group 35-45 ( $0.8 \%$ ).This finding disapproved our third research hypothesis " elderly mothers were more likely to exclusively breastfeed compared to young mothers, this may be attributed to higher frequency registered in this age group, in addition to good advices given by grandmothers who are perceived to be key decision makers when it comes to good parenting. Maternal literacy (25.2\%) was observed to favor exclusive breastfeeding significantly $(\mathrm{p}<0.05)$ was compare to illiterate mothers $(9.8 \%)$. This may be due to their understanding of the health implication of exclusive breastfeeding on infant's health. This is in the support of the finding in Job, Plateau state Nigeria [20].

Our finding is contrary to the result obtained from Ethiopian demographic health survey, which indicated a declining trend of exclusive breastfeeding with the higher maternal education status [21]. This study has indicated a significant difference among employed mothers $(6.5 \%)$ with unemployed mothers $(28.5 \%)$ with regard to exclusive breastfeeding. It also revealed that unemployment is a predication of exclusive breastfeeding which is consistent with the finding of the case study done in Wad Medani Sudan [22]. This might be explaining by the fact of less maternity leave (two month after delivery in our context), which makes employed mothers to have less opportunity to stay at home, compromising exclusive breastfeeding. Mothers also may have to leave their babies to search for a job. These finding calls for course of action to initiate breastfeeding friendly working environment, as well as the extension of maternity leave to encourage mothers to exclusively breastfeed their babies to improve child health outcome.

Our study shows that the religion of mothers exclusively breastfeeds, with the majority about $93.5 \%$ were Christian, $5.7 \%$ were Muslim and $0.8 \%$ were not practicing specific Creed, this need farther investigation how the Religion may affect EBF? This current study showed that mothers who do not have chronic illness constitutes $(91.9 \%)$ out of which a third $(32.5 \%)$ exclusively breastfed compared to $8.1 \%$ of those mothers who had chronic illnesses, and thy undergoing decline of breast milk production due to the stress of illness and might be due to medical advice causing them to opt for mixed feeding. The current study showed that 
Citation: Gore RP, Lomeling FT, Kareialla AH, Fabiano WBA, Mabil CD, et al. (2017) The Associated Factors Hampering Mothers towards Exclusive Breastfeeding EBF through Knowledge, Attitude and Practice (KAP) Studies at Al-Sabah Children Hospital/Juba -South Sudan. J Community Med Public Health : CMPH-101.

the Attendance of Antenatal Care (ANC) clinic (88.6\%) enhanced mothers' knowledge and appreciation of the demands and benefits of exclusive breastfeeding, and empowers them to resist external interferences and pressures. Out of the above percent about a third (31.7\%) exclusively breastfed, this could be due to the health Education about exclusive breastfeeding they received on their ANC visits. Though majority of the mothers attended ANC at least eight percent of them did not had their infants immunized. According to our finding as the age of the infant approached six months, the rate of exclusive breastfeeding decreased significantly, which is similar to other studies done in Uganda, Sudan and Ethiopia [21-23]. This might be due to the fact that postpartum care is traditionally given in the first few months after birth where mothers remain at home, creating a chance to exclusively breastfeed their infants. The other possible reason is that the mother might have introduced complementary feeds for their infant's due to the assumption that breast milk alone could not satisfy their needs as the infant gets older. as the age of the child increases the rate of exclusive breastfeeding decreases as explained by the short birth interval since some mothers had other children of less than two years at home. There was an association between presence of other dependents (elders and toddlers) at home and exclusive breastfeeding, mothers not having other dependents (15.4\%) have higher rate of exclusive breastfeeding compared to those who had other dependents (13.8\%); This could be due to competition for the available resources at home, overworking of the mothers leading to reduced breast milk production as a result complementary foods are introduced early.

\section{Strengths and Limitations}

The use of validated questionnaires, quantitative method of data collection is the strengths of this study. However, the 24-hour recall determining exclusive breastfeeding practice means some infants who were given other liquids regularly may not have received them in the last 24 hours before the interview, which may cause overestimation of the proportion exclusively breastfed. Similarly, Children who have not been receiving other fluids regularly but had been given liquid in the past 24-hour recall method can underestimate the actual EBF rate in the population studied.

Several authors have questioned the validity of the 24-hour recall method [23]. The major criticism of the 24-hour recall method is that it misclassifies too many mothers as exclusively breastfeeding; a proportion of mothers may be providing substances other than breast milk on an irregular, not daily, basis. Many studies have shown that a large proportion of infants who were exclusively breastfed in the previous 24-hours were either not exclusively breastfed during the previous seven days, and/or, not exclusively breastfed since birth [23] Median duration can also be affected by maternal recall, which might be prone to recall and social desirability bias. Therefore, readers are recommended to take this into account during interpretation of these findings. In addition, there are also some variables that were not significantly associated (how- ever known in several studies) with the outcome of interest which might affect the precision. This might be due to the sample size, which might not be adequate to justify the relationships between the explanatory variables and outcome of interest. Therefore, any interpretation of this finding should take into account.

\section{Conclusions \& Recommendations}

Based on the findings, breastfeeding mothers are faced with multiple challenges as they struggle to practice exclusive breastfeeding. Thus, scaling up of EBF among mothers requires concerted efforts and adequate support at

the all levels of South Sudanese Society. The promotion and acceptance of the practice is important in South Sudan where there is high level of poverty, disease burden and low access to clean water and good sanitation. The importance of availability and accessibility of Ante Natal Clinic ANC, training of Healthcare workers and counseling mothers are crucial, also targeting influential members of the family for proper EBF practices and the adoption and implementation of the WHO/UNICEF Global strategy for infants and young child feeding (IYCF) at all healthcare levels in the States of the Republic of South Sudan is paramount to promote the growth, survival and health of infants.

\section{References}

1. Gupta A, Arora V (2007) The State of World's Breastfeeding -Tracking Implementation of the Global Strategy for Infant and Young Child Feeding. International Baby Food Action Network (IBFAN), Asia Pacific. South Asia report.

2. World Health Organization (2003) The Global Strategy for Infant and Young Child Feeding. Geneva.

3. Ip S, Chung M, Raman G, Chew P, Magula N, et al. (2007) Breastfeeding and maternal and infant health outcomes in developed countries. Evid Rep Technol Assess (Full Rep) 153: 1-186.

4. World Health Organization (2009) Infant and young child feeding Model Chapter for textbooks for medical stu-dents and allied health professionals.

5. Jones G, Steketee R, Black R, Bhutta Z, Morris S, et al. (2003) How many child deaths can we prevent this year? Lancet 362: 65-71.

6. Edmond KM, Zandoh C, Quigley MA, Amenga-Etego S, Owusu-Agyei $S$, et al. (2006) Delayed Breastfeeding Initiation Increases Risk of Neonatal Mortality. Pediatrics 117: 380-386.

7. Forbes GB, Adams-Curtis LE, Hamm NR, White KB (2003) Perceptions of the woman who breastfeeds: the role of erotophobia, sexism, and attitudinal variables. Sex Roles: 49: 379-388

8. Mahgoub SEO, Bandeke T, Nneypi M (2002) Breastfeeding in Botswana: Practices, attitudes, patterns, and the socio-cultural factors affecting them. 48: 195-199.

9. Nathoo, Tasnim, Ostry, Aleck (2009) The One Best Way? Breastfeeding History, Politics, and Policy in Canada. Wilfrid Laurier Univ. Press ISBN 978-1-55458-147-154. 


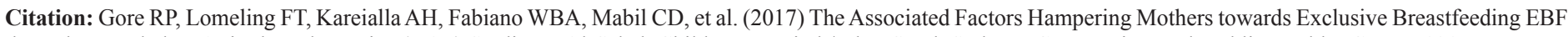
through Knowledge, Attitude and Practice (KAP) Studies at Al-Sabah Children Hospital /Juba -South Sudan. J Community Med Public Health : CMPH-101.

10. WHO (1989) Infant feeding: the physiological basis. Bulletin of the World Health Organization 67: 1-108.

11. Lawrence RA, Lawrence RM (2005) Breastfeeding: a guide for the medical profession. 6th Edition.

12. Forsythe S (2005) Enterobacter sakasakii and other bacteria in powdered infant milk formula. Maternal and Child Nutrition 1: 44-50.

13. Kramer MS, Guo T, Platt RW, Shapiro S, Collet JP, et al. (2002) PROBIT Study Group. Breastfeeding and infant growth: biology or bias? Pediatrics 110: 343-347.

14. Engebretsen IM, Tylleskär T, Wamani H, Karamagi C, Tumwine JK (2008) Determinants of infant growth in Eastern Uganda: a community-based cross-sectional study. BMC Pub Health 8: 418.

15. Black RE, Allen LH, Bhutta ZA, Caulfield LE, de Onis M, et al. (2008) Maternal and Child Undernutrition 1: global and regional exposures and health consequences. Lancet 371: 243-260.

16. Moland K, De Paoli M, Sellen D, Van Esterik P, Leshbari S, et al (2010) Breastfeeding and HIV: Experiences from a Decade of Prevention of Postnatal HIV Transmission in Sub-Saharan Africa. Int Breastfeeding J 5: 5-10
17. 10 Facts on Breastfeeding WHO, July 2012.

18. Breastfeeding impact on child survival and global situation' united nations children's fund, January 2005.

19. UNCIEF Press release.

20. Ogbonna C, Okolo A, Ezeogu A (2000) Factors influencing exclusive breastfeeding in Jos State, Nigeria. West Afr J Med 19: 107-110.

21. Alemayehu T, Haidar J, Habte D (2009) Determinants of Exclusive breastfeeding in Ethiopia. Ethiop J Health Dev 23: 12-18.

22. Haroun HM, Mahfouz MS, Ibrahim BY. Breastfeeding indicators in Sudan; A case study of Wad Medani Town. Sudanese J Public Health 3: 81-90.

23. Engebretsen IM, Wamani $H$, Karamangi C, Semiyaga N, Tumwine J, et al. (2007) low adherence to EBF in eastern Uganda; A Community based crossectional study comparing dietaty recall since birth with 24 hourrecall. BMC Pediatr 7: 1-10. 